\title{
Kompetensi Teknologi, Pedagogi, dan Konten Guru SD Negeri dan Swasta di Kota Cimahi, Jawa Barat
}

\author{
Endi Rochaendi ${ }^{1)}$ Andi Wahyudi ${ }^{2)}$ Riki Perdana ${ }^{3)}$ \\ ${ }^{1)}$ Pendidikan Guru Sekolah Dasar, Universitas Alma Ata, Yogyaakrta, Indonesia \\ E-mail: endi.rochaendi@almaata.ac.id \\ ${ }^{2)}$ Pendidikan Guru Sekolah Dasar, Universitas Alma Ata, Yogyaakrta, Indonesia \\ E-mail: andiwahyudi@alamaata.ac.id \\ ${ }^{3)}$ Pendidikan Guru Sekolah Dasar, Universitas Alma Ata, Yogyaakrta, Indonesia \\ E-mail: rikiperdana@alamaata.ac.id
}

\begin{abstract}
Abstrak. Guru SD dituntut untuk memiliki pengetahuan konten (content) mata pelajaran, pengetahuan pedagogi (pedagogy), dan pengetahuan teknologi (technology) dalam bentuk pengetahuan yang integratif dalam pengelolaan pembelajaran. Penelitian ini bertujuan melihat dan menganalisis faktor-faktor apa saja yang paling dominan dalam membentuk kompetensi guru tersebut dalam aspek pengetahuan konten, pengetahuan pedagogi dan pengetahuan teknologi yang pada gilirannya dapat mengembangkan model pengembangan Technological Pedagogical and Content Knowledge (TPACK) yang sesuai untuk guru SD. Penelitian ini dirancang menggunakan pendekatan kuantitatif, dengan metode deskriptif dan verifikasi. Data dianalisis menggunakan statistik deskriptif dan analisis faktor konfirmatori (CFA) berdasarkan Partial Least Square (PLS). Hasil penelitian menunjukan bahwa faktor-faktor yang pengaruhnya paling dominan adalah pedagogical knowledge $(0,944)$, technological content knowledge $(0,942)$, dan technological pedagogical knowledge (0,935). Sedangkan, pedagogical content knowledge, content knowledge, dan technological knowledge tidak sepenuhnya membentuk TPACK guru SD tersebut.
\end{abstract}

Kata Kunci: sekolah dasar, kompetensi guru, TPACK

\begin{abstract}
Teachers are required to have content knowledge, pedagogy knowledge, and technology knowledge in the form of integrated knowledge in learning management. This study aims to analyze the factors are most dominant in shaping teacher competence in the aspects of content knowledge, pedagogical knowledge, and technology knowledge which in turn can develop a development model for Technological Pedagogical and Content Knowledge (TPACK) suitable for elementary school teachers. This research was designed using a quantitative approach, with descriptive and verification methods. Data were analyzed using descriptive statistics and confirmatory factor analysis (CFA) based on Partial Least Square (PLS). The results showed that the factors with the most dominant influence were pedagogical knowledge (0.944), technological content knowledge (0.942), and technological pedagogical knowledge (0.935).Meanwhile, pedagogical content knowledge, content knowledge, and technological knowledge did not fully form the TPACK of teacher.
\end{abstract}

Keywords: elementary school, teacher competence, TPACK.

\section{PENDAHULUAN}

Sebagai salah satu wadah pengembangan sumber daya manusia, pendidikan memiliki peran penting dan strategis. Pendidikan dapat meningkatkan standar hidup individu dan daya saing ekonomi [1,2]. Dalam konteks tersebut diartikan bahwa pendidikan merupakan sarana transformasi dan perbaikan kualitas kecakapan hidup (life skill) sumber daya manusia secara signifikan dalam aspek kecerdasan intelektual, kecerdasan spiritual, dan kecerdasan sosial.

Dewasa ini program pembangunan pendidikan Indonesia telah menjadi fokus dan perhatian utama serta menjadi langkah-langkah terpenting untuk berkompetisi dalam perkembangan dunia global dan revolusi industri 4.0. Melalui kebijakan Merdeka-Belajar (MB) diharapkan dapat 
melaksanakan pemajuan pendidikan dengan cara menumbuhkembangkan peserta didik agar memiliki kemampuan (1) berkebhinekaan global, (2) bergotong royong, (3) kreatif, (4) bernalar kritis, (5) mandiri, dan (6) beriman, bertakwa kepada Tuhan YME, dan berakhlak mulia [3].

Namun, upaya-upaya tersebut belum sepenuhnya terimplementasi dengan optimal. Data dalam aspek peningkatan mutu pendidikan masih memperlihatkan trend stagnan dan kurang memuaskan apabila dilihat dari hasil tes PISA. Pada tahun 2018, Indonesia menduduki peringkat 72 dari 78 negara yang ikut serta dalam kegiatan Programme for International Student Assessment (PISA) dalam test Matematika, tes sains dan tes literasi membaca. Hasil test PISA menunjukkan bahwa kemampuan peserta didik Indonesia di bidang Matematika meraih skor rerata sebesar 379 dari rerata skor OECD sebesar 487. Sedangkan untuk tes sain rata-rata peserta didik Indonesia mencapai sebesar 389 dengan dari rerata skor OECD sebesar 489 dan tes literasi membaca rata-rata peserta didik Indonesia mencapai sebesar 371 dengan dari rerata skor OECD sebesar 487. Bisa disimpulkan bahwa mutu pendidikan Indonesia masih cukup rendah dibandingkan dengan negara-negara lainnya (OECD). Penyebab prestasi peserta didik yang kurang memuaskan, salah satunya dimungkinkan oleh keterbatasan kemampuan guru di bidang kemampuan pedagogi, kemampuan pengetahuan dan kemampuan profesional.

Kekurangoptimalan prestasi peserta didik tersebut sebagaimana dijelaskan dalam Renstra Kemendikbud RI Tahun 2020-2024, ditenggarai oleh kemampuan guru dalam melaksanakan proses pembelajaran pada satuan pendidikan belum sepenuhnya efektif dan perlu perbaikan pada kemampuan pedagogi. Di samping itu, sebagian besar guru dalam melaksanakan efektivitas pembelajaran hanya berfungsi untuk mentransfer pengetahuan bukan sebagai fasilitator pembelajaran serta dalam pengelolaan pembelajarannya belum sepenuhnya mengembangkan karakter dan membangkitkan motivasi belajar di kalangan peserta didik. Di beberapa kasus ketika guru memberikan pertanyaan, kurang lebih 90 persen dari tanggapan siswa hanya berupa jawaban satu kata. Selanjutnya berdasarkan Restra tersebut dijelaskan pula bahwa tata cara ketika guru bertanya tidak menyentuh pada aspek kedalaman dan keluasan substansi proses bahan kajian, belaum sepenuhnya memunculkan keterampilan untuk berpikir tingkat tinggi (higher order thinking skills) dan kompetensi untuk menjelaskan logika pemikiran [3].

Sementara itu disisi lain, Uji Kompetensi Guru (UKG) memperlihatkan hasil yang cukup memprihatinkan. Dalam hal ini, hasil UKG paling tinggi yang dicapai guru-guru Sekolah Dasar tahun 2019 hanya mencapai skor 54,8. Kekurangberhasilan pencapaian hasil ujian tersebut kemungkinan bersumber dari kekurangmampuan guru dimaksud dalam penguasaan pengetahuan, penguasaan sikap, dan penguasaan keterampilan dalam merancang, mengelola, melaksanakan penilaian dan evaluasi hasil pembelajaran termasuk di dalamnya ketidakberhasilan guru dalam menguasai pengetahuan mengenai struktur, konsep, dan pola pikir keilmuan yang harus dimiliki, dikuasai, dihayati, dan diaktualisasikan oleh guru.

Dalam upaya perbaikan dan peningkatan pengelolaan pembelajaran pada satuan pendidikan sehingga dapat meningkatkan mutu pendidikan sangat dibutuhkan guru profesional yang memiliki kemampuan pedagogik dan kemampuan profesional. Menurut Permendikbud Republik Indonesia Nomor : 57 Tahun 2012 tentang Uji Kompetensi Guru dijelaskan bahwa kemampuan pedagodik diartikan sebagai kemampuan guru untuk (1) mengenal karakteristik dan potensi peserta didik, (2) menguasai teori belajar dan prinsip-prinsip pembelajaran yang efektif, (3) menguasai perencanaan dan pengembangan kurikulum, (4) menguasai langkah-langkah pembelajaran yang efektif, dan (5) menguasai sistem, mekanisme, dan prosedur penilaian. Sedangkan yang dimaksud dengan kemampuan profesional adalah kemampuan untuk (1) menguasai materi, struktur, konsep, dan pola pikir keilmuan yang mendukung mata pelajaran yang diampu guru, (2) menguasai metodologi keilmuan sesuai bidang tugas yang dibebankan kepada guru, dan (3) menguasai hakikat profesi guru. Dengan memiliki kemampuan tersebut di atas, diharapkan guru dapat mengelola proses pembelajaran yang selaras dan sejalan dengan kaidahkaidah pedagogik dalam memberikan fasilitasi terhadap pengembangan potensi diri dan karakter peserta didik serta dapat memahami sepenuhnya materi pelajaran dan memiliki penguasaan akan teori, aplikasi, pendekatan, teknik/metode keilmuan, teknologi, atau seni yang berkesesuaian dengan mata pelajaran yang diampu. Pendek kata, penguasaan terhadap kemampuan pedagogik dan kemampuan profesional dapat menghasilkan lulusan dengan kemampuan tinggi dalam menjawab berbagai tantangan global $[4,5]$.

Era globalisasi dan kemajuan teknologi dalam bentuk Revolusi Industri 4.0 dengan memanfaatkan Internet of Things (IoT), Big Data, percetakan 3D, Artifical Intelligence (AI), kendaraan tanpa pengemudi (drone), rekayasa genetika, robot, dan lain-lain mengakibatkan berbagai perubahan di segala aspek kehidupan, termasuk di bidang pendidikan yang berpadanan dengan kemajuan teknologi informasi dan komunikasi (TIK) secara digital. Digitalisasi TIK dalam pengelolaan pendidikan diharapkan dapat menata dan memaksimalkan proses pembelajaran pada satuan pendidikan dengan dukungan alat, media dan sarana teknologi pembelajaran sehingga mengembangkan suasana pembelajaran yang aktif, inovatif, kreatif dan menyenangkan (PAKEM). Namun demikian, digitalisasi TIK dalam pengelolaan pendidikan menuntut penguasaan keterampilan dan pengetahuan baru bagi guru-guru, sehubungan digitalisasi TIK membutuhkan, mencerminkan, dan melakukan rekonstruksi pada berbagai keterampilan siswa di berbagai bidang pembelajaran, baik dengan menggunakan metode pembelajaran lawas maupun anyar [6].

Keterampilan dan pengetahuan guru yang dibutuhkan dalam menjalankan implementasi digitalisasi TIK dalam proses pembelajaran adalah Technological Pedagogical Content Knowledge atau TPACK [7] yaitu kerangka kerja dari sebuah konten pembelajaran yang didalamnya berisi pengintegrasian pengetahuan teknologi, pengetahuan 
pedagogik dan pengetahuan konten sehingga menjadikan proses pembelajaran menjadi lebih efektif dan menyenangkan. Konsep tersebut didasarkan atas inisiatif Shulmans yang mengajukan teori bahwa interaksi pengetahuan pedagogik atau pedagogical knowledge (PK) dan pengetahuan konten atau content knowledge (CK) dapat meningkatkan pedagogical content knowledge (PCK) [8]. Mengingat pentingnya teknologi dalam pembelajaran abad ke-21, selanjutnya para peneliti lainnya mencoba untuk memasukkan pengetahuan teknologi atau technological knowledge (TK) sebagai bagian dari pengetahuan guru [9]. Sebagaimana interaksi PK dan CK dapat meningkatkan PCK, dengan memasukkan TK diharapkan dapat menghasilkan bentuk lain dari pengetahuan seperti technological content knowledge (TCK), technological pedagogical knowledge (TPK), sehingga pada akhirnya menjadi technological pedagogical content knowledge (TPACK).Pada akhirnya, ketiga bentuk dasar dari pengetahuan guru (TK, PK, and CK) dan dampak dari pengetahuan yang muncul dari interaksi ketiga bentuk tersebut dapat membentuk tujuh konstruk dari kerangka TPACK [10].

Tujuh konstruk dari kerangka TPACK dihasilkan dari hubungan sinergis antara komponen yang saling beririsan dari Content (C) yaitu tentang materi pembelajaran yang akan dipelajari, Pedagogic (P) yaitu teori belajar, prinsip-prinsip pembelajaran, dan kurikulum pembelajaran, dan Technology (T) yaitu akses internet, perangkat lunak aplikasi kurikulum, model pembelajaran, program animasi, laboratorium virtual dan lain sebagainya dalam sebuah konteks pembelajaran dengan membentuk sebuah Knowledge (K). Tujuh konstruk tersebut, diantaranya adalah : (1) Pengetahuan konten (Content Knowledge) adalah kemampuan untuk menguasai pemahaman tentang materi, struktur, konsep dan pola pikir keilmuan yang mendukung mata pelajaran yang diampu, (2) Pengetahuan pedagogik (Pedagogical Knowledge) diartikan sebagai kemampuan untuk menguasai pemahaman karakteristik peserta didik, teori dan prinsip-prinsip pembelajaran, pengembangan kurikulum serta pengetahuan mengenai penilaian dan evaluasi proses dan hasil belajar, (3) Pengetahuan teknologi (Technological Knowledge) adalah kemampuan untuk mengoperasikan komputer dan perangkat lunak lainnya, (4) Pengetahuan konten pedagogi (Pedagogy Content Knowledge) yaitu pengetahuan, sikap, dan keterampilan untuk merancang, mengelola serta melaksanakan penilaian dan evaluasi pembelajaran termasuk di dalamnya penguasaan terhadap materi pelajaran, penguasaan teori, aplikasi, pendekatan, teknik/metode keilmuan, teknologi, atau seni yang relevan dengan mata pelajaran yang diampu, (5) Pengetahuan konten teknologi (Technology Content Knowledge) yaitu pengetahuan dan keterampilan penguasaan teknologi informasi dan komunikasi dalam rangka kepentingan proses pembelajaran, (6) Pengetahuan pedagogik teknologi yaitu pengetahuan penguasaan teknologi informasi dan komunikasi untuk berkomunikasi dan mengembangkan diri serta (7) Pengetahuan tentang konten, pedagogi dan teknologi yang terintegrasi (Technology Pedagogy and Content Knowledge) adalah kegiatan mengintegrasikan TIK ke dalam pengelolaan pembelajaran di dalam kelas sehingga menjadikan proses pembelajarannya menjadi lebih aktif, inovatif, kreatif dan menyenangkan karena dukungan akses internet, software, media pembelajaran dan sarana TIK lainnya. Terjadinya multi interaksi antar komponen dapat dilakukan melalui penyatupaduan materi pelajaran, pedagogi dan teknologi dalam sebuah konten yang unik dan sinergis berbasis TIK [11].

Pada saat ini, guru Sekolah Dasar baik guru Negeri maupun guru Swasta dituntut untuk memiliki pengetahuan konten (content) mata pelajaran yang diampu, pengetahuan pedagogi (pedagogy) terkait bagaimana guru tersebut menjalankan proses pembelajaran (sejak perencanaan, pelaksanaan, sampai dengan penilaian dan evaluasinya), dan pengetahuan teknologi (technology) sebagai komponen integrasi pengetahuan dari tiga unsur utama dalam TPACK pada abad digital untuk mendukung terbentuknya penguasaan sikap, pengetahuan dan keterampilan abad ke-21 bagi peserta didiknya. Namun berdasarkan beberapa studi menyebutkan bahwa penerapan TPACK mengalami banyak hambatan. Hambatan tersebut diantaranya adalah : (1) interpretasi guru-guru terhadap TPACK, (2) pengelolaan proses pembelajaran dan (3) keterbatasan sarana teknologi dan pembiayaan. Dalam aspek interpretasi, permasalahan utama adalah belum sepenuhnya kerangka TPACK dikuasai oleh para guru Sekolah Dasar serta masih diinterpretasikan secara beragam oleh para guru. Dalam hal ini, proses pembelajaran tetap menerapkan fragmentasi pola konvensional (tradisional) dari tahun ke tahun. Dalam aspek pelaksanaan proses pembelajaran, sebagian besar guru Sekolah Dasar kurang memiliki penguasaan teknologi, literasi informasi dan media pembelajaran berteknologi digital dan keterbatasan akses internet di masing-masing satuan pendidikan menurut kewilayahan geografi. Dalam aspek sarana, terdapat permasalahan yang berkaitan dengan keterbatasan kepemilikan sarana TIK dan ketidakcukupan anggaran pembiayaan satuan pendidikan untuk membayar biaya pengadaan, perawatan dan pemeliharaan sarana TIK.

Dari beberapa hambatan tersebut di atas, interpretasi dan preferensi beragam para guru terhadap konsepsi TPACK kemungkinan menjadi sumber permasalahan utama. Dalam hal ini, interpretasi ditenggarai muncul karena kurangnya persepsi yang tepat mengenai pengintegrasian TPACK dalam proses pembelajaran. TPACK belum sepenuhnya digunakan untuk kepentingan penguasaan materi, struktur, konsep, dan pola pikir keilmuan yang mendukung mata pelajaran yang diampu serta kemampuan dalam pengelolaan pembelajaran guna mewujudkan suasana dan proses pembelajaran yang sesuai dengan kaidah pedagogik dalam rangka memfasilitasi pengembangan potensi diri dan karakter peserta didik.

Sehubungan dengan hal tersebut, perlu dilakukan penelitian yang dapat memberikan gambaran mengenai faktor-faktor apa saja yang paling dominan dalam membentuk kompetensi guru dalam aspek pengetahuan teknologi, pedagogi, dan konten, sehingga pada gilirannya dapat mengembangkan model pengembangan TPACK yang sesuai untuk guru SD. Selanjutnya, hasil penelitian ini diharapkan mampu memberikan sumbangsih pengetahuan di bidang teknologi, pedagogi dan pengetahuan konten guna meningkatkan proses pengelolaan dan penyelenggaraan pendidikan pada satuan 
pendidikan Sekolah Dasar khususnya dalam pengelolaan proses pembelajaran. Selain itu, penelitian ini dapat bermanfaat untuk melakukan refleksi mengenai model dan pengembangan TPACK dan faktor-faktor antecedent yang mempengaruhinya dalam meningkatkan pemahaman dan kompetensi guru Sekolah Dasar.

\section{METODE PENELITIAN}

Penelitian ini memanfaatkan pendekatan kuantitatif, dengan metode deskriptif dan verifikasi. Sesuai dengan karakteristik variabel yang diteliti, penelitian ini dilaksanakan melalui kegiatan survey berskala 7. Tempat penelitian dilakukan di Kecamatan Cimahi Utara Kota Cimahi Provinsi Jawa Barat. Populasi penelitian adalah guru-guru SD baik SD Negeri maupun SD Swasta di Kota Cimahi berjumlah 596 guru. Selanjutnya terkait dengan pemilihan responden menggunakan metode proportional random sampling sehingga didapatkan sampel guru sebanyak 240 orang guru SD.

Dalam teknik pengumpulan data menggunakan angket yang disebar kepada responden menggunakan Google Form yang telah diuji validitas dan reliabilitasnya. Variabel yang diteliti dalam penelitian ini meliputi : (1) pengetahuan konten (CK), (2) pengetahuan teknologi (TK), (3) pengetahuan pedagogi (PK), (4) pengetahuan konten teknologi (TCK), (5) pengetahuan pedagogik berbasis teknologi (TPK), dan (6) pengetahuan konten pedagogi (PCK).

Data dianalisis menggunakan statistik deskriptif (mean, standar deviasi, dan kategori) dan dengan analisis faktor konfirmatori (CFA) berdasarkan Partial Least Square (PLS). Analisis ini hanya mencakup model pengukuran.

\section{HASIL DAN PEMBAHASAN}

Profil responden guru SD berdasarkan kelamin dan status sekolah disajikan pada Tabel 1. Tabel ini menginformasikan adanya 47 guru laki-laki di SD Negeri dan 19 di SD Swasta, dan 131 guru perempuan di SD Negeri dan 43 guru perempuan di SD Swasta.

Variabel TPACK yang menjadi fokus penelitian ini direfleksikan oleh 6 (enam) dimensi pengetahuan yang saling terkait, diantaranya: (1) pengetahuan konten (CK), (2) pengetahuan teknologi (TK), (3) pengetahuan pedagogi (PK), (4) pengetahuan konten teknologi (TCK), (5) pengetahuan pedagogik berbasis teknologi (TPK), dan (6) pengetahuan konten pedagogi (PCK). Setiap dimensi masing-masing diukur oleh 2 (dua) indikator.

Variabel laten TPACK itu termasuk cukup tinggi dengan capaian reratanya adalah sebesar 5,373 dari nilai ideal 7,000. Capaian dari dimensi pengetahuan konten (CK) adalah yang paling tinggi di antara semua dimensi tersebut dengan kategori tinggi, sedangkan yang lainnya cukup tinggi. Adapun dimensi yang capaiannya lebih rendah daripada dimensi-dimensi lainnya pada variabel ini mencakup tiga dimensi terakhir yaitu yang terkait dengan pengetahuan konten teknologi (TCK), pengetahuan pedagogik berbasis teknologi (TPK), dan pengetahuan konten pedagogi (PCK). Analisis lebih lanjut mengungkapkan bahwa capaian dari semua dimensi dalam variabel laten TPACK ini sudah sejalan dengan capaian dari masing-masing dimensinya. Berdasarkan tanggapan para guru
SD sebagai responden dalam penelitian ini mengenai variabel laten TPACK tersebut, dapat dinyatakan hal-hal pokok sebagai berikut:

1. Pengetahuan konten atau Content Knowledge (CK) sebagai dimensi pertama dalam variabel TPACK ini mencapai kategori tinggi yang berarti bahwa guru sudah benar-benar memiliki pengetahuan mengenai subject matter (konten atau materi yang diajarkannya). Dimensi ini dapat diukur melalui tingkat penguasaan materi pelajaran dan intensitas peningkatan kemampuan menguasai materi pelajaran. Pada dasarnya para guru tersebut dinilai sudah sangat menguasai materi pelajaran yang diampunya. Guru juga umumnya dinilai sudah secara maksimal berupaya meningkatkan kemampuannya dalam menguasai materi pelajaran dengan terus melakukan update. Para guru tersebut, terlepas dari aspek gender, usia, lama kerja, status sekolah, maupun wilayah lokasi sekolah, memiliki kecenderungan yang sama, yaitu samasama sudah sangat menguasai subject matter.

2. Pengetahuan teknologi atau Technology Knowledge (TK) sebagai dimensi kedua pada variabel TPACK ini memiliki capaian skor rerata yang termasuk pada kategori cukup tinggi dalam hal ini. Dimensi technology knowledge ini terkait dengan various technologies and their features yang dapat diukur di sini menggunakan tingkat penguasaan teknologi informasi dan tingkat kemampuan beradaptasi dengan teknologi informasi baru. Berdasarkan perhitungan, guru dinilai sudah cukup mampu dalam menguasai teknologi informasi saat ini untuk kepentingan dirinya maupun untuk kepentingan proses pembelajaran daring dan luring. Guru juga dinilai sudah cukup mampu dalam beradaptasi dengan kemajuan teknologi informasi yang berkembang saat ini, seperti penggunaan gadget dan video conference, termasuk aplikasi pendukungnya.

3. Pengetahuan pedagogi atau Pedagogical Knowledge (PK) sebagai dimensi ketiga pada variabel TPACK ini memiliki capaian skor rerata yang juga termasuk pada kategori cukup tinggi. Lebih lanjut dapat dinyatakan bahwa dimensi ini mengacu pada processes or methods of teaching yang pengukurannya dapat dilakukan melalui tingkat penerapan media pembelajaran ICT dalam proses pembelajaran dan tingkat relevansi model pembelajaran dengan media pembelajaran. Pada umumnya guru mempersepsi bahwa mereka sudah cukup mampu dalam menerapkan media pembelajaran ICT pada proses pembelajaran. Guru tersebut juga mempersepsi bahwa model pembelajaran yang digunakan sudah cukup relevan dengan ketersediaan media pembelajaran sebagai salah satu fasilitas pembelajaran yang penting pada saat ini.

4. Pengetahuan konten teknologi atau Technological Content Knowledge (TCK) merupakan dimensi keempat pada variabel TPACK dengan capaian skor rerata yang berada pada kategori cukup tinggi pula. Pada intinya dimensi ini berkenaan dengan subject matter representation with technology yang indikator untuk mengukurnya terdiri atas tingkat relevansi materi pembelajaran dengan penerapan ICT dan frekuensi pelaksanaan pembelajaran melalui ICT. Pada intinya para guru mempersepsi materi pembelajaran 
yang diberikan kepada para peserta didik itu sudah cukup relevan dengan penerapan ICT. Secara umum para guru tersebut juga sudah cukup sering melaksanakan pembelajaran melalui ICT, terutama ini didasarkan pada pengalaman mereka akhir-akhir ini terkait pembelajaran daring pada masa pandemi COVID-19.

5. Pengetahuan pedagogik berbasis teknologi atau Technological Pedagogical Knowledge (TPK) sebagai dimensi kelima pada variabel TPACK berada pada kategori cukup tinggi sesuai dengan capaian skor rerata yang didapatkan. Dimensi TPK ini mengacu pada kriteria using technology to implement different teaching methods. Pengukurannya ada dua, yaitu tingkat relevansi penerapan ICT dalam berbagai metode pengajaran dan frekuensi penerapan ICT dalam berbagai metode pengajaran. Hasil pengungkapan dari analisis deskriptif menunjukkan bahwa rata-rata guru mempersepsi adanya penerapan ICT yang cukup relevan dalam berbagai metode pengajaran sehingga hampir semua materi pengajaran dapat cocok diterapkan dengan menggunakan ICT. Lebih lanjut dikemukakan bahwa guru rata-rata sudah cukup sering menerapkan ICT tersebut dalam berbagai macam metode pengajarannya.

6. Pengetahuan konten pedagogi atau Pedagogical Content Knowledge (PCK) merupakan variabel keenam atau terakhir pada variabel laten TPACK, yang capaiannya termasuk pada kategori cukup tinggi. Fokus dari dimensi PCK itu adalah pada teaching methods for different types of subject matter. Lebih lanjut, PCK ini adalah dimensi yang diukur dengan dua indikator yaitu tingkat relevansi penerapan ICT dalam mata pelajaran lain dan frekuensi penerapan ICT dalam mata pelajaran lain. Hasil analisis deskriptif selanjutnya menunjukkan bahwa guru mempersepsi adanya penerapan ICT yang cukup relevan dalam mata pelajaran lain selain yang diampunya, yang dapat dilakukan melalui kolaborasi antar-mata-pelajaran. Berikutnya adalah guru mempersepsi bahwa para guru sudah cukup sering menerapkan ICT dalam mata pelajaran lain. Untuk dimensi ini tidak terdapat perbedaan yang signifikan terkait profil responden dari aspek gender, usia, lama kerja, tetapi terdapat perbedaan yang cukup signifikan terkait aspek status sekolah dan lokasi sekolah. Sekolah dengan status negeri umumnya lebih tinggi capaiannya dibandingkan dengan sekolah berstatus swasta.

Model pengukuran pada konstruk TPACK memiliki variabilitas tertentu dalam kaitannya dengan kontribusi dari masing-masing dimensinya. Semua dimensi terbukti dapat mencerminkan konstruk TPACK guru ini. Dari hasil pengukuran tersebut didapatkan bahwa semua dimensi berkontribusi besar terhadap pembentukan konstruk TPACK guru SD ini.

Mengacu pada rumusan masalah, dapat dijawab di sini bahwa dimensi-dimensi yang pengaruhnya paling menonjol adalah pedagogical knowledge, technological-content knowledge, dan technological-pedagogical knowledge dengan nilai loading masing-masing sebesar 0,944; 0,942; dan 0,935 . Namun, dimensi-dimensi lain seperti pedagogical-content knowledge, content knowledge, dan technological knowledge juga penting dalam membentuk konstruk TPACK ini.
Semua upaya peningkatan tersebut tidak dapat berjalan dengan lancar tanpa adanya pengaruh dari faktor-faktor lain seperti kepemimpinan kepala sekolah dan fasilitas pembelajaran digital. Faktor-faktor tersebut dapat mendorong pengembangan pengetahuan pedagogik yang tepat dalam memadukan konten, pedagogi, dan teknologi.

Pengaruh kepemimpinan kepala sekolah terhadap pengembangan TPACK ditegaskan] bahwa pimpinan sekolah (termasuk kepala sekolah, wakil kepala sekolah, guru senior, atau pengawas) dapat menyelaraskan kebutuhan TPACK melalui penyesuaian kurikulum, penyediaan perangkat atau fasilitas yang relevan dan sumber-sumber digital, termasuk melatih dan mengembangkan kapasitas guru dalam optimalisasi TPACK [12]. Berbagai perubahan dan langkahlangkah inovasi dalam pembelajaran perlu diantisipasi oleh pimpinan sekolah dalam rangka mempersiapkan guru baru atau guru senior sebagai cetakbiru atau rancangan bagi pengembangan TPACK.

Lebih lanjut, pengaruh kepemimpinan kepala sekolah terhadap pengembangan TPACK adalah bahwa peran koordinasi dari kepala sekolah dapat menjadi unsur yang menunjang keberhasilan guru dalam mengembangkan berbagai aspek dalam TPACK, termasuk aspek teknologi, pedagogi, organisasi, dan perubahan dalam aspek teknologi informasi dan komunikasi [13]. Pada intinya, kepala sekolah perlu menjadi orang pertama yang siap menghadapi perubahan sistemik dan menularkannya kepada para guru sehingga memudahkan fasilitasi penerapan teknologi dalam pengembangan TPACK guru di sekolah. Tanpa kepemimpinan kepala sekolah yang efektif, pengembangan TPACK hanya akan jalan di tempat tidak akan maju ke depan.

Masih terkait dengan pengaruh kepemimpinan kepala sekolah terhadap pengembangan TPACK guru melalui penerapan model TPACK yang efektif itu memerlukan kepemimpinan kepala sekolah yang bertanggung jawab untuk menentukan arah, mengembangkan SDM (guru dan staf), dan mendesain ulang program persiapan guru agar siap ke lingkungan TPACK yang sesungguhnya [14]. Dalam melakukan semua tantangan itu, kepala sekolah disarankan untuk melaksanakan diagnostik terkait TPACK sehingga dapat memberikan dukungan dan pedoman kepada para guru dalam proses pengembangan TPACK siap pakai dan tidak terlalu membebani aktivitas utama guru. Saat ini masih banyak kepala sekolah yang melakukan pendelegasian kewenangan kepada guru terkait pengembangan TPACK tanpa adanya arahan, bimbingan, atau pengawasan yang melekat.

Fasilitas pembelajaran ini erat kaitannya dengan unsur teknologi dalam pengembangan TPACK guru itu sendiri. Guru pada umumnya sudah sangat terbiasa dengan content atau materi pembelajaran. Guru juga umumnya sudah terbiasa dengan unsur pedagogi karena menjadi guru bukan hanya sekedar mampu menguasai materi mata pelajaran tetapi perlu juga mengetahui cara memberikan pengajaran secara bermakna kepada peserta didiknya melalui model, metode, strategi, dan media yang tepat, termasuk bagaimana menyusun asesmen untuk mengevaluasi keberhasilan belajar siswa. 
Integrasi unsur technology ke dalam content dan pedagogy tersebut menjadi lengkap sebagai satu kesatuan TPACK.

Pada awalnya fokus kompetensi dan pengetahuan guru terletak pada unsur pedagogi dan konten atau biasa disebut PCK [15]. Namun, seiring dengan kemajuan teknologi informasi dan komunikasi dewasa ini di berbagai bidang, termasuk pendidikan, guru semakin dituntut untuk lebih memiliki kemampuan dalam memadukan dan merancang kurikulum dan teknologi untuk pengajaran yang inovatif. Selain itu, juga sebelumnya telah menekankan bahwa integrasi teknologi dan fasilitas pembelajaran berbasis teknologi digital dalam proses pembelajaran merupakan isu penting dalam pengembangan TPACK guru, terutama guru sains [16]. Pengembangan guru sains sangat dipengaruhi oleh berbagai faktor, terutama kemandiriannya dalam literasi teknologi, mengingat sains berkaitan dengan konsep yang abstrak [17,18]. Dengan demikian, adalah wajar jika sekolah perlu menekankan pada isu-isu pengembangan fasilitas pembelajaran digital karena saat ini aspek tersebut memerlukan perhatian lebih untuk kepentingan guru, siswa, dan proses pembelajaran. Proses pembelajaran digital dalam hal ini akan menjadi acuan dalam mengembangkan keterampilan berpikir kritis dan kreatif [19]. Beberapa kendala terkait fasilitas pembelajaran digital di SD negeri dan swasta yang perlu diantisipasi adalah akses ke fasilitas digital serta kecukupan dan kecakapan staf (termasuk guru) yang menguasai fasilitas pembelajaran digital tersebut. Isu-isu tersebut sebenarnya dapat diantisipasi jika sekolah fokus dan konsisten terhadap perubahan teknologi.

Tabel 1. Profil Responden Guru Berdasarkan Status Sekolah dan Jenis Kelamin

\begin{tabular}{cccc}
\hline $\begin{array}{c}\text { Status } \\
\text { Sekolah }\end{array}$ & Laki-laki & $\begin{array}{c}\text { Jenis Kelamin } \\
\text { Perempuan }\end{array}$ & Jumlah \\
\hline Negeri & 47 & 131 & 178 \\
Swasta & 19 & 43 & 62 \\
\hline Jumlah & 66 & 174 & 240 \\
\hline
\end{tabular}

\section{SIMPULAN}

Penelitian ini mengungkapkan faktor-faktor determinan pengembangan TPACK guru SD Negeri maupun Swasta. Hasil analisis memperlihatkan bahwa pengetahuan pedagogi (PK), pengetahuan konten teknologi (TCK) dan pengetahuan pedagogik berbasis teknologi (TPK) merupakan faktor-faktor yang dominan dalam membentuk pengembangan TPACK. Faktor-faktor lain seperti pengetahuan konten pedagogi (PCK), pengetahuan konten (CK) dan pengetahuan teknologi (TK) kontribusinya masih belum optimal dibandingkan sebelumnya dalam membentuk konstruk TPACK sehingga guru perlu lebih memahami keterpaduan antara hal-hal tersebut melalui kegiatan pembiasaan dan adaptasi.

Penelitian berikutnya dapat mencakup penelaahan yang lebih luas, tidak hanya di SD di Kabupaten Majalengka Provinsi Jawa Barat, tetapi diperluas ke lokasi lain atau jenjang pendidikan yang lebih tinggi.

\section{DAFTAR PUSTAKA}

[1] Ball, S. J. (2009). Privatising education, privatising education policy, privatising educational research: Network governance and the 'competition state'. Journal of education policy, 24(1), 83-99.

[2] Buckner, E. S. (2017). The changing discourse on higher education and the nation-state, 1960-2010. Higher Education, 74(3), 473-489.

[3] Peraturan Menteri Pendidikan dan Kebudayaan Republik Indonesia Nomor 22 Tahun 2020 tentang Rencana Strategis Kementerian Pendidikan dan Kebudayaan Tahun 2020-2024.

[4] Fadel, C., \& Trilling, B. (2010). 21st Century Skills: Learning for Life in Our Times. Education Review.

[5] Lee, C. S., Tan, D. T., \& Goh, W. S. (2004). The next generation of e-learning: Strategies for media rich online teaching and engaged learning. International Journal of Distance Education Technologies (IJDET), 2(4), 1-17.

[6] Griffin, P., \& Care, E. (2014). Assessment and teaching of 21st century skills: Methods and approach. Springer.

[7] Muilenburg, L., \& Berge, Z. (2015). Revisiting teacher preparation. Quarterly Review of Distance Education Journal Issue, 16(2), 93-105.

[8] Shulman, L. S. (1986). Those who understand: Knowledge growth in teaching. Educational researcher, 15(2), 4-14.

[9] Angeli, C., \& Valanides, N. (2009). Epistemological and methodological issues for the conceptualization, development, and assessment of ICT-TPCK: Advances in technological pedagogical content knowledge (TPCK). Computers \& education, 52(1), 154-168.

[10] Mishra, P., \& Koehler, M. J. (2006). Technological pedagogical content knowledge: A framework for teacher knowledge. Teachers college record, 108(6), 1017-1054.

[11] Harris, J., Mishra, P., \& Koehler, M. (2009). Teachers' technological pedagogical content knowledge and learning activity types: Curriculum-based technology integration reframed. Journal of research on technology in education, 41(4), 393-416.

[12] Thomas, T., Herring, M., Redmond, P., \& Smaldino, S. (2013). Leading change and innovation in teacher preparation: A blueprint for developing TPACK ready teacher candidates. TechTrends, 57(5), 55-63.

[13] Avidov-Ungar, O., \& Shamir-Inbal, T. (2017). ICT coordinators'tpack-based leadership knowledge in their roles as agents of change. Journal of information technology education, 16(1).

[14] Graziano, K. J., Herring, M. C., Carpenter, J. P., Smaldino, S., \& Finsness, E. S. (2017). A TPACK diagnostic tool for teacher education leaders. TechTrends, 61(4), 372-379.

[15] Jang, S.-J., \& Chen, K.-C. (2010). From PCK to TPACK: Developing a transformative model for preservice science teachers. Journal of Science Education and Technology, 19(6), 553-564. 
[16] Koehler, M., \& Mishra, P. (2009). What is technological pedagogical content knowledge (TPACK)? Contemporary issues in technology and teacher education, 9(1), 60-70.

[17] Wahyudi, A., Liliasari, T. Supriyanti, \& Nahadi. (2019). The development and validation of critical and creative thinking test in enzyme for undergraduate chemistry course. Unnes science education journal. 8 (1), 76-83

[18] Perdana, R., Yani, R., Jumadi, J., Rosana, D. (2019). ssessing students' digital literacy in senior high school. Jurnal Pendidikan Indonesia. 8 (2), 169-177.

[19] Wahyudi, A. (2020). Profil keterampilan berpikir kritis dan kreatif calon guru kimia. Jurnal orbital. 4 (2), 99110 . 